\title{
ANALISIS SISTEM AKUNTANSI INSTANSI PADA KANTOR PERWAKILAN BADAN KEPENDUDUKAN DAN KELUARGA BERENCANA NASIONAL PROVINSI SULAWESI UTARA
}

\author{
Yefie Ignasia Worung \\ Jenny Morasa \\ Jantje Tinangon
}

yefie.ignasia@gmail.com

\begin{abstract}
The central government is a party that is given the responsibility and rights to run the government systems, and social services to the society. In order to fulfill these duties, central government needs a system that can assist the government in carrying out its functions. Accounting Institution System is one embodiment of the systems of government that regulate the flow of goods, services and funds into supporting the implementation of the government's job.

The purpose of this study is to analyze the suitability of the SAI management system procedures and regulations, analyze the course of the reconciliation process, and analyze the use of information systems related to Accounting Institution System on BKKBN SULUT.

The analytical method used is descriptive comparative method which is a method for finding answers fundamentally about causation by analyzing factors of occurrence or the appearance of certain phenomena.

The results showed that the organizational structure has described the separation of responsibilities and authority, especially the things related to the SAI that consist of SAK and SIMAK$B M N$, the implementation of the SAI in BKKBN SULUT has not been fully implemented in accordance with applicable regulations, both internal and external reconciliation generally been accomplished by the procedure and only experienced by technical errors, while the information relating to the SAI system has been implemented properly and structured.
\end{abstract}

\section{PENDAHULUAN}

\subsection{Latar Belakang}

Salah satu perwujudan prosedur pengelolaan dana pemerintah pusat adalah Sistem Akuntansi Pemerintah Pusat (SAPP) yang membawahi Sistem Akuntansi Instansi (SAI) dan Sistem Akuntansi Bendahara Umum Negara (SA-BUN). SAPP diatur dalam Peraturan Menteri Keuangan Republik Indonesia Nomor 171/PMK.05/2007 tentang Sistem Akuntansi dan Pelaporan Keuangan Pemerintah Pusat. Melalui prosedur dan sistem inilah dana negara digunakan, dimanfaatkan, dan dipertanggungjawabkan dengan baik.

Proses pengelolaan SAK dan SIMAK-BMN sangat dipengaruhi oleh pengelolaan di setiap tingkat struktural karena prinsip penggabungan laporan yang dilakukan secara berjenjang. Salah satu contoh adalah proses pelaporan SAK. Laporan yang dihasilkan oleh setiap satuan kerja atau Unit Akuntansi Pengguna Anggaran (UAKPA) digabungkan oleh unit akuntansi di atasnya pada tingkat Unit Akuntansi Pembantu Pengguna Anggaran Wilayah (UAPPA-W). Laporan tingkat wilayah digabungkan lagi di tingkat Unit Akuntansi Pembantu Pengguna Anggaran Eselon I (UAPPA-E1). Laporan antar tingkat Eselon I digabungkan di tingkat Unit Akuntansi Pengguna Anggaran (UAPA) sehingga dihasilkan Laporan Keuangan K/L. Selanjutnya setiap K/L menyampaikan Laporan Keuangan kepada Menteri Keuangan. Laporan tingkat K/L, menjadi bahan penyusunan Laporan Keuangan Pemerintah Pusat (LKPP).

Konsekuensi dari pengelolaan SAK dan SIMAK-BMN adalah akan terjadi akumulasi kesalahan jika tingkatan paling bawah atau UAKPA menyajikan data yang tidak akurat. Selain itu, kondisi setiap kantor perwakilan yang tidak seragam sangat berpengaruh menimbulkan keragaman kualitas laporan yang dihasilkan. Contoh keragaman kondisi dapat dilihat dari sebaran kualitas maupun pendidikan Sumber 
Daya Manusia (SDM) di setiap kantor perwakilan K/L yang sudah pasti berbeda-beda.

Walaupun telah ada aplikasi sistem yang mengelola keuangan dan barang jasa tetapi bukan berarti semua sudah terawasi dan terlaksana dengan baik. Akhirnya semua harus kembali ke Peraturan dan Undang-Undang (UU) yang menaungi proses pengelolaan hal-hal tersebut. Sistem prosedur di tubuh organisasi itu sendiri yang perlu di jaga agar tidak keluar dari jalur yang sebenarnya, sebab aplikasi sistem hanyalah alat. SDM lah yang memegang kontrol penuh terhadap aplikasi sistem. Bintang yang banyak pada aplikasi sistem bukanlah salah aplikasi tersebut tapi salah SDM nya karena data pendukung tidak lengkap. Stok barang dalam aplikasi sistem yang kurang tepat bukanlah salah aplikasi tersebut tapi salah SDM nya yang lalai dalam perhitungan stok barang.

Berbagai uraian di atas menjadi bahan pertimbangan penulis untuk melakukan penelitian mengenai Sistem Akuntansi Instansi, baik secara manual maupun komputerisasi di salah satu instansi Pemerintah Pusat. yaitu Perwakilan Badan Kependudukan dan Keluarga Berencana Nasional (BKKBN) Propinsi Sulawesi Utara.

Pada tahun 2011, BKKBN memperoleh opini Wajar Tanpa Pengecualian oleh Badan Pemeriksa Keuangan. Tetapi pada tahun 2012 turun menjadi Wajar Dengan Pengecualian lalu kemudian meningkat lagi menjadi Wajar Tanpa Pengecualian pada tahun 2013. Sebuah instansi yang beberapa kali mendapatkan opini Wajar Tanpa Pengecualian oleh BPK secara umum prosedur yang dilakukan harusnya sudah benar. Tetapi, secara kasat mata pelayanan BKKBN yang diberikan kepada masyarakat terlihat belum optimal. Hal ini ditunjukkan dengan pelayanan Keluarga Berencana yang belum merata dan pendistribusian alat dan obat-obatan yang belum maksimal. Hal inilah yang mendorong penulis untuk melakukan penelitian mengenai Sistem Akuntansi Instansi pada Satuan Kerja BKKBN Propinsi Sulawesi Utara.

\subsection{Rumusan Masalah}

Berdasarkan uraian latar belakang masalah diatas, maka penelitian ini merumuskan masalah sebagai berikut.

1. Apakah Sistem Akuntansi Instansi pada Perwakilan BKKBN Propinsi Sulawesi Utara secara umum telah sesuai dengan sistem prosedur pengelolaan keuangan yang berlaku?

2. Apakah Proses Rekonsiliasi pada Perwakilan BKKBN Propinsi Sulawesi Utara telah dilaksanakan dengan benar?

3. Apakah penggunaan Sistem Informasi yang berhubungan dengan Sistem Akuntansi Instansi pada Perwakilan BKKBN Propinsi Sulawesi Utara telah berjalan dengan baik?

\subsection{Tujuan Penelitian}

Berdasarkan rumusan masalah di atas, maka tujuan penelitian ini untuk

1. menganalisis kesesuaian pengelolaan Sistem Akuntansi Instansi pada Perwakilan BKKBN Propinsi Sulawesi Utara dengan sistem prosedur pengelolaan keuangan yang berlaku.

2. Untuk menganalisis Proses Rekonsiliasi pada Perwakilan BKKBN Propinsi Sulawesi Utara.

3. Untuk menganalisis penggunaan Sistem Informasi yang berhubungan dengan Sistem Akuntansi Instansi pada Perwakilan BKKBN Propinsi Sulawesi Utara.

\section{TINJAUAN PUSTAKA dan KERANGKA PEMIKIRAN}

\subsection{Sistem Akuntansi Instansi}

Sistem Akuntasi Instansi merupakan sistem akuntansi yang dilaksanakan oleh K/L selaku pengguna anggaran. SAI memproses data transaksi keuangan, barang, dan transaksi lain yang dilaksanakan oleh K/L (Mahmudi, 2011:216).

SAI terdiri dari dua sub sistem yaitu Sistem Akuntansi Keuangan (SAK) yaitu subsistem dari SAI yang menghasilkan informasi mengenai LRA, Neraca, dan Catatan atas Laporan Keuangan milik K/L dan Sistem Informasi Manajemen dan Akuntansi Barang Milik Negara (SIMAK-BMN) yaitu subsistem dari SAI yang merupakan serangkaian prosedur yang saling berhubungan untuk mengolah dokumen sumber dalam rangka menghasilkan informasi untuk menyusun Neraca dan Lapoaran Barang Milik Negara serta laporan manajerial lainnya menurut ketentuan yang berlaku. 


\subsection{Kerangka Pemikiran}

Dalam Penelitian ini, Penulis fokus kepada Sistem Akuntansi Instansi dengan meneliti kedua unsur sistem yang ada di dalamnya yaitu SAK dan SIMAK-BMN. SAK dan SIMAK-BMN memiliki alur tersendiri dalam proses pelaksanaannya, dan penulis mencoba meneliti hal tersebut. pelaksanaan SAK dan SIMAK-BMN pada akhirnya akan berujung kepada Rekonsiliasi yang bertujuan untuk menyamakan data antara kedua sistem tersebut atau biasa disebut dengan Rekonsiliasi Internal, serta menyamakan data antara SAI dengan Sistem yang ada pada Kementerian Keuangan, dalam hal ini KPPN.

Gambar 2.1

Kerangka Berpikir

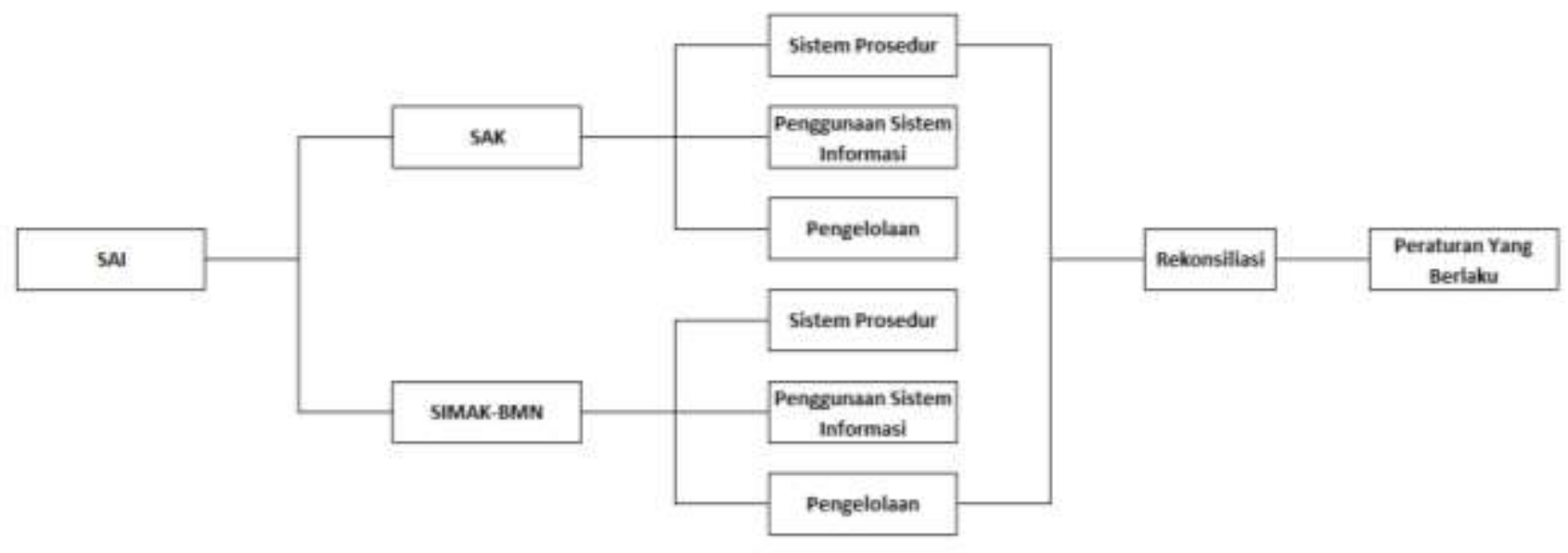

Sumber : Data Olahan (2015)

SAI yang membawahi SAK dan SIMAK BMN akan memiliki output yang baik apabila Sistem Prosedur, Penggunaan Sistem Informasi, dan Pengelolaannya dilaksanakan dengan baik. Oleh karena itu, penulis menganalisis SAI dengan melihat ketiga hal tersebut. Sistem Prosedur, Penggunaan Sistem Informasi, dan Pengelolaannya akan terlihat jelas pada proses rekonsiliasi yang dilaksanakan setiap bulannya. Apabila proses rekonsiliasi terlaksana dengan lancer tanpa ada hambatan kekurangan data dan ketidaksamaan jumlah, maka secara umum SAI telah dilaksanakan dengan baik dan sesuai dengan peraturan yang berlaku.

\section{METODE PENELITIAN}

\subsection{Jenis dan Sumber Data}

Jenis penelitian ini termasuk penelitian Deskriptif. Penelitian deskriptif menurut Mohammad Nazir (2006:54) adalah suatu metode dalam meneliti status kelompok manusia, suatu objek, suatu set kondisi, suatu sistem pemikiran ataupun suatu kelas peristiwa pada masa sekarang. Tujuan dari penelitian ini : untuk membuat deskriptif / gambaran, melukiskan secara sistematis, faktual dan akurat mengenai fakta-fakta, sifat-sifat serta hubungan antar fenomena yang diselediki. Data yang akan digunakan dalam penelitian adalah data primer dan data sekunder.

\subsection{Prosedur Pengumpulan Data}

Dalam penelitian ini, data dikumpulkan melalui tiga tahap. Pada tahap pertama peneliti akan melakukan studi pustaka yaitu dengan mencari literatur yang berhubungan dengan penelitian yang akan dilakukan. Pada tahap kedua peneliti mengumpulkan data dengan Metode dokumentasi lalu pada tahap ketiga peneliti melakukan wawancara dengan pejabat atau pegawai yang berhubungan langsung dengan penelitian ini.

\subsection{Teknik Analisis Data}

Metode penelitian yang digunakan dalam penelitian ini adalah deskriptif komparatif. Deskriptif komparatif adalah suatu jenis metode penelitian yang ingin mencari jawab secara mendasar tentang sebab 
akibat dengan menganalisis faktor-faktor terjadinya atau munculnya fenomena tertentu (Mohammad Nazir, 2003:58).

\section{HASIL PENELITIAN DAN PEMBAHASAN}

\subsection{Hasil Penelitian}

Hasil penelitian menunjukkan bahwa Data-data SAI berasal dari kompilasi SAK dan SIMAKBMN. Pada BKKBN Propinsi Sulawesi Utara, pejabat SAI bertanggung jawab langsung kepada Kepala Satuan Kerja (Kesatker) dalam hal ini Kepala Perwakilan BKKBN Propinsi Sulawesi Utara.

UAKPA melakukan proses penyusunan laporan keuangan. Dalam proses penyusunan laporan keuangan ini menggunakan aplikasi komputer yang disebut dengan aplikasi SAKPA (Sistem Akuntansi Kuasa Pengguna Anggaran). dalam Pelaksanaannya menggunakan dokumen sumber antara lain ; DIPA, revisi DIPA, SPM (Surat Perintah Membayar) yang ditanda tangani oleh Pejabat Penguji dan Perintah Pembayaran, SP2D (Surat Perintah Pencairan Dana) yang dikeluarkan oleh KPPN berdasarkan SPM yang diajukan kepada KPPN. Pengelolaan Akuntansi Barang milik negara menggunakan SIMAK-BMN oleh Kementerian Keuangan Direktorat Jenderal Perbendaharaan. Dengan Laporan BMN yang dihasilkan kemudian dilakukan rekonsiliasi kepada Unit Akuntansi Keuangan untuk penyusunan neraca SAKPA.

Pelaksanaan rekonsiliasi data antara satker di BKKBN Propinsi SULUT dengan KPPN selaku Bendahara Umum Negara (BUN) dimulai dengan Rekonsiliasi Internal. Rekonsiliasi Periode Berjalan dilakukan dengan membandingkan nilai persediaan, BMN intrakomptabel per akun neraca per jenis transaksi dan akun pembalik jurnal korolari dari SPM belanja modal yang diinput di SIMAK-BMN dengan akun - akun neraca yang terkait dengan BMN dan jurnal korolari dari belanja modal yang diinput di SAKPA yang dibukukan pada bulan sesuai dengan isian parameter bulan (Contoh : rekonsiliasi bulan April berarti yang di rekon adalah nilai persediaan, BMN intrakomtabel per akun dan jenis transaksi, akun korolari dari transaksi yang dibukukan dan diposting di bulan April).

Rekonsiliasi eksternal adalah rekonsiliasi data antara satker di lingkungan BKKBN dengan KPPN selaku BUN. Rekonsiliasi ini dilaksanakan dengan tujuan pencocokan data transaksi keuangan yang diproses oleh aplikasi SAI oleh satker di lingkungan BKKBN dengan aplikasi SA-BUN yang dikelola oleh KPPN. Pelaksanaan rekonsiliasi dilaksanakan setiap bulan, dengan penyampaian BAR paling lama 7 hari kerja bulan berikutnya.

\subsection{Pembahasan}

Perwakilan BKKBN Propinsi Sulawesi Utara merupakan salah satu instansi vertikal yang ada di daerah. Dari pengamatan yang dilakukan penulis, Perwakilan BKKBN Propinsi Sulawesi Utara hanya memiliki satu satker walaupun pelaksanaan kegiatannya sampai di tingkat Kabupaten dan Kota. Perwakilan BKKBN Propinsi Sulawesi Utara bermitra dengan sedikitnya empat kota dan sebelas kabupaten yang ada di Sulawesi utara. Dana yang disalurkan ke setiap Kota dan Kabupaten adalah Dana APBN Murni. Sistem pelaporan keuangan hanya dilakukan di tingkat Propinsi. Oleh karena itu, UAKPA dan UAPPA-W adalah sama. dalam hal ini, penanggung jawab dan Pengelola SAI bertugas juga sebagai Penanggung Jawab UAKPA dan UAKPB.

Sesuai ketentuan, dana APBN murni seharusnya dikelola penuh oleh Perwakilan BKKBN SULUT. Namun pada kenyataannya, Perwakilan BKKBN SULUT sering memberikan dana ke Kabupaten kota untuk dikelola oleh mereka sendiri tapi dalam pengawasan Perwakilan BKKBN Sulawesi Utara. Hal ini jelas saja melanggar ketentuan tetapi mereka mengaku akan sangat kelimpungan apabila mengelola dana untuk kota dan kabupaten sendiri sebab hanya ada satu Satker saja.

Dalam internalnya, Satker BKKBN SULUT telah menetapkan dan memisahkan petugas pelaksana SAI yaitu petugas SAK yang disebut dengan UAKPA dan petugas BMN yang disebut dengan UAKPB. Namun Penanggung Jawab SAI adalah petugas UAKPA itu sendiri.

UAKPA dan UAKPB dalam menjalankan tugasnya dibantu oleh staf bendahara untuk mengetahui lebih rinci tentang jumlah uang yang keluar melalui SPP, SPM dan SP2D.

LRA disampaikan secara teratur setiap bulannya. Menurut wawancara dengan penanggungjawab SAI, BKKBN selalu mengirimkan data-data kepada KPPN maupun Eselon I tepat waktu setiap bulannya.

Secara umum, sistem prosedur yang berkaitan dengan SAK telah dilakukan dengan baik oleh 
BKKBN SULUT. Kendala-kendala yang sering terjadi adalah kendala teknis seperti lupa menginput SPM ke dalam sistem, atau salah menginput nomor SPM dan SP2D.

BKKBN menyusun rekapan transaksi persediaan dalam laporan persediaan setiap bulan. Hal ini sangat membantu dalam pengelolaan BMN. Apabila ada barang persediaan yang rusak, maka dicatat dan dibuat laporan barang dengan kondisi yang rusak berat dan telah diusulkan penghapusannya. Salah satu contoh barang dengan kondisi ini adalah obat-obatan yang rusak akibat banjir dan tidak bisa terpakai lagi, dan mobil yang rusak dibakar masa di salah satu kabupaten. Sedangkan apabila ada barang persediaan yang hilang, maka dibuat laporan barang hilang tahunan yang diusulkan penghapusannya.

Selanjutnya, berdasarkan data yang diperoleh, BKKBN membuat laporan mutasi BMN maupun barang persediaan di Neraca sehingga kita bisa melihat nominal BMN dan barang persediaan tersebut. Laporan ini dibuat setiap semester. Terdapat beberapa macam laporan, seperti Laporan Mutasi Barang Rinci dan Ringkas yang sudah dilampirkan bersama tulisan ini.

Pada akhir periode, petugas UAKPB melakukan pengecekan Barang milik negara dan mencatat perubahan-perubahan yang terjadi terkait dengan BMN. Akhir periode yang dimaksudkan disini adalah periode tahunan, sehingga BKKBN SULUT cukup kesulitan menghitung semua BMN yang ada. Sudah diusulkan pada awal tahun 2014 untuk melakukan perhitungan BMN setiap bulan dan membuat laporan rekapan setiap semester tetapi rupanya hal ini belum berjalan dengan baik. Pada akhir tahun 2014 baru dilakukan perhitungan kembali BMN yang ada sehingga history keluar masuk barang fisik per bulan tidak tercatat dengan baik. Memang setiap barang masuk dan keluar selalu dicatat dalam sistem. Tetapi stock opname di gudang atau di lapangan yang hanya setahun sekali membuat stok yang ada di sistem dan stok real nya berbeda.

Rekonsiliasi internal dilaksanakan setiap akhir bulan. Tetapi yang di rekonsiliasi adalah data dari kedua aplikasi SAI, bukan data real dengan data aplikasi sehingga belum tentu jumlah persediaan atau uang yang ada di sistem adalah sama dengan jumlah dan nilai real.

Proses rekonsiliasi membutuhkan banyak data pendukung, tetapi seringkali data pendukung kurang lengkap sehingga rekonsiliasi memakan waktu lebih lama dari yang seharusnya, padahal masih ada tahapan rekonsiliasi eksternal dengan BPK yang sedang menunggu. Seringkali SPM dan SP2D tidak lengkap saat dilakukan rekonsiliasi. SPM dan SP2D yang dipegang oleh beberapa orang menjadi kendala dalam proses ini. seharusnya SPM dan SP2D diserahkan kepada satu orang sehingga pada saat diperlukan, data tersebut lebih mudah ditemukan.

Rekonsiliasi eksternal yang dimulai dari penyerahan data dari Satker ke KPPN selaku BUN berlangsung setiap awal bulan, dan BKKBN SULUT mengklaim bahwa mereka selalu tepat waktu menyerahkan Berita Acara Rekonsiliasi (BAR) dan ADK yang sudah di backup sebelumnya serta dokumen pendukung rekonsiliasi yang dibutuhkan. Dari hasil pengamatan penulis, patuhnya Satker BKKBN SULUT dalam hal rekonsiliasi ke KPPN dikarenakan KPPN Manado menetapkan peraturan berupa sanksi penghambatan pencairan dana jika belum melaksanakan rekonsiliasi.

Setelah BAR diserahkan, dilakukan rekonsiliasi antara SAI yang ada di Satker dengan SA-BUN yang dikelola oleh KPPN. Proses rekonsiliasi bisa saja memakan waktu agak lama yang disebabkan oleh ketidaksamaan data atau jumlah pada kedua sistem ini. selama ada ketidaksamaan data atau jumlah pada SAI dan SA-BUN maka rekonsiliasi dinyatakan belum selesai. Oleh karena itu, Satker harus mencari titik kejanggalan yang mengakibatkan ketidaksamaan tersebut. Untuk melacak kejanggalan yang ada, Satker menggunakan data ADK yang sudah di backup sebelumnya.

Ketidaksamaan data biasanya disebabkan karena Human Error (Kesalahan Manusia), yaitu kesalahan dalam perekaman data SPM dan SP2D. kesalahan yang terjadi misalnya salah dalam pengetikan kode SPM dan SP2D contoh : No. 5036I diketik 50361. Salah ketik antara huruf I dengan angka 1 sudah dapat membuat status TIDAK SAMA. Kesalahan tersebut bisa dibilang kesalahan kecil karena hanya tinggal mengubah kode saja kemudian me restore ulang data. Dan kesalahan ini tidak mengubah dan mempengaruhi nilai akhir dari laporan keuangan. Dengan kata lain laporan telah SAMA tapi SALAH.

Dari wawancara penulis dengan salah satu pejabat SAI, sering terjadi kesalahan seperti ini. Salah satu contoh yang sering terjadi adalah kesalahan pembebanan dalam belanja antara dua bagian. Pada satker ini, setiap bidang atau kegiatan mempunyai beberapa kode SPM dan SP2d yang sama. Seringkali 
karena Human Error, belanja untuk bidang atau kegiatan A, terinputkan pada belanja untuk bidang atau kegiatan B karena keduanya memiliki beberapa kode atau akun yang sama.

Apabila KPPN mengetahui hal ini pada rekonsiliasi pada bulan di awal tahun, maka biasanya KPPN langsung mengembalikan ADK atau datanya kepada Satker untuk diperbaiki. Namun seringkali kesalahan ini diketahui pada saat rekonsiliasi akhir tahun karena itu Satker harus menilik kembali datadata dari awal tahun untuk mencari kesalahan yang menyebabkan nilai akhir Tidak Sama.

Selain itu salah satu penyebab adalah mengenai pajak. Misalnya pajak honor. Pembagian Honor di BKKBN SULUT terdiri atas dua jenis yaitu Honor Pembantu Operasional dan Honor Pembantu Kegiatan yang menghasilkan output, dan pajak dari honor tersebut ditanggung oleh BKKBN SULUT. Yang sering terjadi kesalahan adalah pada pencatatan pembayaran Honor Pembantu Kegiatan yang menghasilkan output. Misalnya jumlah honor untuk satu orang dalam kegiatan Hari Keluarga Berencana adalah Rp.2.000.000,- (Dua Juta Tiga Ratus Ribu Rupiah) ditambah pajak sebesar 5\% atau Rp. 100.000,(Seratus Ribu Rupiah). Sering terjadi bahwa jumlah nominal pajak tidak diinputkan ke SAI karena SSP nya tercecer. Yang diinputkan hanyalah jumlah honornya saja. Sehingga pada saat rekonsiliasi, data yang ada dalam SAI dan SA-BUN dinyatakan tidak sama.

Sebagian besar kesalahan dalam rekonsiliasi memang ada pada Satker, tetapi kadang KPPN juga bisa melakukan kekeliruan. Hal ini biasanya terjadi pada kasus SSP. Bisa jadi pada saat Bendahara Satker menyetor pajak di kantor pos atau bank, para petugas kantor pos atau bank tersebut lupa mengirimkan lembaran SSP untuk kantor KPPN sehingga KPPN tidak mencatatnya dalam SA-BUN, dan pada saat rekonsiliasi hasilnya menjadi tidak sama.

\section{PENUTUP}

\subsection{Kesimpulan}

Berdasarkan dari hasil penelitian dan pembahasan pengaruh penerapan GCG terhadap DER, DAR dan ROE, NPM maka dapat disimpulkan beberapa kesimpulan sebagai berikut:

1. Pelaksanaan SAI pada Satuan Kerja Perwakilan BKKBN Propinsi Sulawesi Utara belum sepenuhnya dilaksanakan sesuai dengan ketentuan yang berlaku. Sistem Prosedur SAK dan SIMAK-BMN serta hal-hal teknis memang sudah dilaksanakan dengan baik dan sesuai dengan ketentuan yang ada. Tetapi ada beberapa hal yang terjadi di lapangan yang tidak sesuai dengan ketentuan. Misalnya masih ada yang mencoba merubah PAGU anggaran padahal sudah tercatat di KPPN, dan pengelolaan dana bantuan yang disalurkan kepada masyarakat masih belum terkontrol dengan baik. Buktinya penyimpangan pada bantuan sosial masih terjadi. Selain itu penyimpangan juga terjadi pada tahun 2012 yang menyebabkan opini BPK yang pada tahun sebelumnya adalah WTP menurun menjadi WDP. Hal ini disebabkan karena BKKBN menyewakan Guest House yang sedianya adalah untuk penggunaan internal kepada masyarakat, tetapi pendapatan sewa tidak dimasukkan ke dalam Pendapatan resmi BKKBN.

2. Rekonsiliasi pada umumnya sudah berjalan dengan baik. Kesalahan memang ada tetapi sebagian besar merupakan kesalahan teknis.

3. Sistem Informasi sudah dilaksanakan dengan baik. SAK dan SIMAK BMN berperan penting dalam proses rekonsiliasi yaitu memudahkan satker untuk membandingkan, mencocokkan serta menganalisis data yang ada pada SAKPA dan SIMAK-BMN. Pada rekonsiliasi internal juga, disesuaikan stok barang persediaan yang ada pada aplikasi persedian dan SIMAK-BMN serta SAKPA. Setiap tahun aplikasi di update dan dilakukan pembaharuan secara berkala.

\subsection{Saran}

Berdasarkan hasil penelitian yang telah dilakukan ini, peneliti dapat memberikan saran sebagai acuan bagi pihak yang berkepentingan:

1. Teknis dari Sistem Akuntansi Instansi pada Perwakilan BKKBN SULUT pada umumnya sudah berjalan sesuai dengan ketentuan, tetapi ada baiknya petugas atau operator SAK dan SIMAK-BMN salah satunya adalah staf keuangan sehingga dapat meminimalisir kesalahan penginputan data akibat kesalahan komunikasi dengan bagian keuangan

2. Pengelolaan keuangan secara manual juga harus lebih diperhatikan, terutama mengenai dana yang 
disalurkan kepada masyarakat lewat bantuan sosial maupun dana kegiatan sehingga kegiatan fiktif dan bantuan sosial yang ditarik kembali tidak akan terjadi lagi

3. Sebaiknya penanggungjawab SPM diserahkan kepada satu orang saja sehingga pada saat penginputan, tidak ada SPM yang tercecer dan terpencar pada beberapa orang. Begitu juga dengan surat setoran pajak, sebaiknya setelah bendahara selesai menyetorkan ke kantor pos atau bank, SSP segera diserahkan kepada operator SAI untuk kemudian inputkan ke dalam sistem.

\section{DAFTAR PUSTAKA}

BPK. Peraturan Menteri Keuangan No. 171 tahun 2007. [PDF] (http://jdih.bpk.go.id/wpcontent/uploads/2012/03/2007-PMK-171-SAPKPP.rar, diakses tanggal 2 Februari 2014)

BPPK. Depkeu. Laporan Keuangan PKKIP (Pelaporan Keuangan Pemerintah) [PPTX] (http://www.bppk.depkeu.go.id/webanggaran/index.php/unduh/doc_details/118--laporan-keuanganpkkip, diakses tanggan 2 Februari 2014)

BPPKDepkeu. Strategi Pengadaan Barang. (http://www.bppk.depkeu.go.id/bdk/palembang/attachments/204_Strategi\%20Pengadaan\%20Barang. pdf, diakses tanggal 2 Februari 2014)

BPKP. Sistem Akuntansi Pemerintah Pusat $\quad$ (SAPP). (http://www.bpkp.go.id/sesma/konten/285/Sistem-Akuntansi-Pemerintah-Pusat-SAPP.bpkp, diakses tanggal 6 Januari 2014)

Forum Dosen Akuntansi Sektor Publik. 2006. Standar Akuntansi Pemerintahan Telaah Kritis PP Nomor 24 Tahun 2005. BPFE Yogyakarta.

Kemenag. Aplikasi SIMAK-BMN [PDF] (http://www.lpmpjateng.go.id/web/index.php/arsip/artikel/670seputar-pengadaan-barang-dan-jasa-pemerintah, diakses tanggal 6 Februari 2014)

KSAP. Standar Akuntansi Pemerintahan. [PDF] (http://www.ksap.org/sap/standar-akuntansipemerintahan/, diakses tanggal 5 Januari 2014)

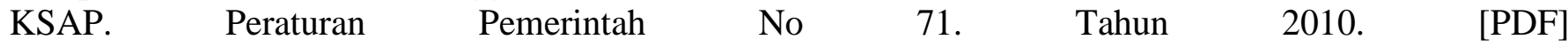
(http://www.ksap.org/pp\%2071/PP_71_TAHUN_2010.pdf, diakses diakses tanggal 5 Januari 2014)

KSAP. Standar Akuntansi Pemerintahan Berbasis Akrual. [PDF] (http://www.ksap.org/pp\%2071/LAMPIRAN1/lampiran\%201_1.pdf, diakses tanggal 5 Januari 2014)

KSAP. Standar Akuntansi Pemerintahan Berbasis Kas Menuju Akrual.. (http://www.ksap.org/pp\%2071/LAMPIRAN2/Lampiran_II_SAP_Berbasis_Kas_Menuju_Akrual.pd f, diakses tanggal 5 Januari 2014)

KSAP. Presentasi Implementasi SAP Pada Pemerintah Pusat - KSAP. [PPS] (www.ksap.org/Seminar/presentasi_pempus_090805.pps, diakses tanggal 5 Januari 2014)

Kemenag. Ringkasan Penyusunan [PDF] (http://rocan.kemenag.go.id/download/Ringkasan\%20Penyusunan\%20RKAKL.pdf, diakses tanggal 8 Januari 2014)

Mursyidi. 2009. Akuntansi Pemerintahan Di Indonesia. Edisi Kedua. PT Refika Aditama.

Mahsun M, Sulistiyowati F, Purwanugraha H.A. 2013. Akuntansi Sektor Publik. Edisi Ketiga. BPFE Yogyakarta.

LPMPJateng. Seputar Pengadaan Bang Jan Pemerintah. (http://www.lpmpjateng.go.id/web/index.php/arsip/artikel/670-seputar-pengadaan-barang-dan-jasapemerintah, diakses tanggal 6 Februari 2014)

PU. Peraturan Menteri Keuangan No. 196 Tahun 2009. [PDF] (http://www.pu.go.id/satminkal/itjen/peraturan/keu/pmk_196_2009\%20BELANJA\%20SUBSIDI\%2

0BELANJA\%20LAIN-LAIN.pdf, diakses tanggal 2 Februari 2014)

Solihin, D. 2006. Pendanaan Pusat dan Daerah. PT Artifa Duta Prakarsa

Zarkasyi, Moh. Wahyudi. 2008. Good Corporate Governance. Alfabeta. Bandung. 